\title{
Evaluation of the Most Significant Treatment Factors for Maize Grain Yields and Total Microbial Count in Long Term Agricultural Experiment (LTAE), Kenya
}

\author{
Wambua Alex Mwaniki ${ }^{1, ~ *, ~ K o s k e ~ J o s e p h ~}{ }^{2}$, Mutiso John², Mulinge Wellington ${ }^{3}$, \\ Kibunja Catherine ${ }^{3}$, Eboi Bramuel ${ }^{1}$ \\ ${ }^{1}$ Department of Planning and Statistics, Ministry of Agriculture, Livestock and Fisheries, Nairobi, Kenya \\ ${ }^{2}$ Department of Mathematics and Computer Science, Moi University, Eldoret, Kenya \\ ${ }^{3}$ Kenya Agricultural and Livestock Research Organization, Nairobi, Kenya
}

Email address:

mwanikialex19@gmail.com (W. A. Mwaniki),mwaniki.alex@hotmail.com (W. A. Mwaniki)

${ }^{*}$ Corresponding author

\section{To cite this article:}

Wambua Alex Mwaniki, Koske Joseph, Mutiso John, Mulinge Wellington, Kibunja Catherine, Eboi Bramuel. Evaluation of the Most Significant Treatment Factors for Maize Grain Yields and Total Microbial Count in Long Term Agricultural Experiment (LTAE), Kenya. Science Journal of Applied Mathematics and Statistics. Vol. 5, No. 6, 2017, pp. 188-199. doi: 10.11648/j.sjams.20170506.11

Received: September 18, 2017; Accepted: October 8, 2017; Published: November 11, 2017

\begin{abstract}
Agriculture and its related economic activities form the main livelihood for Kenya population. The sector faces numerous challenges that have led to food insecurity in the country. Maize production plays a significant role in the country' economic development contributing significantly to the national overall Gross Domestic Product (GDP). Declining maize grain yield is one of the major challenges that require interventions to avert the looming food crisis. To address the challenge various Long Term Agricultural Experiments (LTAE) and studies on soil fertility maintainance options have been developed. However, such studies have explored only single factors at a time with limited application of robust statistical application. Statistical procedures could offer best set of few treatment factors that explain the maize grain yields in LTAEs in Kenya and beyond. The focus of this paper was the application of robust statistical methods in obtaining set of minimum treatment factors that could be used in the determination maize grain yield in LTAE. Specifically, the paper sought to describe the trend in maize grain yield over the experimental period, characterize the input factors for maize grain yield and to determine the most significant treatment factors for maize grain yield and total microbial population count (bacteria, fungi, actinomycetes, rhizobia). The primary data was summarized from LTAE in National Agricultural Research Laboratories (NARL), Kabete under the Kenya Agriculture and Livestock Research Organization (KALRO) and secondary data imputed for experimental points falling outside the set field experimental design points. Two treatment factors were isolated (Farm Yard Manure (FYM) and Nitrogen and Phosphorus (NP)) at their low factor levels as the most significant treatment factor in maximizing the maize grain yield and total microbial population count. It was possible to select a minimum set of treatment factors in LTAE that are critical in predicting the maize grain yield.
\end{abstract}

Keywords: Robust Statistical Analysis, Long Term Agricultural Experiments, Maize Trends,

Total Microbes Population Count

\section{Introduction}

Agricultural experiments are key undertaking for the development for most countries. Over the years the growth of scientific agricultural experiments advancement has transformed the agricultural experimentation, [20]. In agricultural practices, experimentation occupies a crucial undertaking in the improvement of farming, [29]. The development of various forms of scientific experiments for crop improvement has led to considerable advancement in 
finding the optimal agricultural conditions for crop production. This has been motivated to produce enough food to feed the high and growing population, [10]. Having a minimal set of treatment factors to guide experiments in maize grain yield and total microbial population count is important. This saves researcher time and recurrent costs involved. To address some of the most critical constraints (soil fertility, soil quality, microbial activities) facing agriculture sector, LTAE are developed. LTAE are experiments developed to run for a long time and used to monitor systems and follow up possible changes in maize grain yields. Establishing the best set of minimal treatment factors in maize grain yield with minimum threshold of microbial population for production has great benefits and ensures achievements of higher outputs and good returns for the smallholder and further promotes farming as a business.

\subsection{Challenges Facing Maize Production in Kenya}

The main challenges associated with the declining maize grain yields have been linked to the decline in the soil fertility. Soil degradation is a widespread problem. Resource poor, subsistence farming and low-inputs agricultural practices are among the major factors that push further the soil degradation. The stress of the increased world population, land sub-divisions, decreasing vegetation, increased soil erosion, climate changes, emerging global warming and Carbon Dioxide $\left(\mathrm{CO}_{2}\right)$ emission have had a negative effects on the maize grain yield too. These have resulted to; low productivity, low income, rural-urban migration, household and national food insecurity, [7]. Declining per capita production and deterioration of the environment, poor soil physical properties, decreased soil aggregation, bulky density, water infiltration, decrease in amount and quality of available water, loss of vegetation cover and biological diversity have also been studied, [30].

\subsection{The Problem}

Continuous crop production in the various agricultural LTAE including maize experiments trials has pointed out decline in essential soil nutrients either through erosion and/or through nutrient loss through crop uptake. These have resulted to progressive low maize grain yields, low levels of the optimal total microbial population count and high production costs for sustained production of the crop. LTAE in NARL on soil fertility maintenance concluded that a set of critical treatment factors existed below which it became extremely difficult to maintain maize and beans yields, [12]. Preliminary results from LTAE indicate that continuous cropping has resulted to significant decline in crop yields regardless of the land management options under consideration, [17].

To address these changes therefore, different scientific, agronomic and statistical modeling are of paramount value for responding to this noble recommendation to avert the food and nutrition security in the country and beyond. The application of robust statistical modelling have been successfully been employed in industrial and such could offer great relief to the situation for prescribing a parsimonious treatment factors.

Specifically, the main problem within the LTAE and in small-scale maize farmers has been continued maize grain yield decline despite the various measures for soil management practices. The finding from the paper would presents a different dimension for ensuring and ratifying the declining trend in the maize experiments and offer better solutions to farmers.

\subsection{Scope}

The paper considered two response variables, maize grain yield $\left(\mathrm{y}_{1}\right)$ and the total microbial population count $\left(\mathrm{y}_{2}\right)$. The paper presented an analysis of LTAE in KALRO and used sample years (based on data availability and data normalcy) data for building robust treatment factors. This was measured and reported in $\mathrm{kgha}^{-}$of the maize grain yield only and used for modeling the significant treatment factors. The total microbial population $\left(\mathrm{y}_{2}\right)$ was used as an indicator and measure of soil fertility extracted as sum of the total common microbes that included bacteria, fungi, actinomycetes and rhizobia.

\subsection{Soil Fertility Studies}

Soil fertility management agricultural experiments have been undertaken by both the developed and the developing counties with the aim of understanding the effects of soil fertility on crop yields. In East Africa such initiatives started back in 1930's to address issues of soil fertility through the combination of vegetative fallows and animal manure, [17].

Several studies have since been carried out on maize yield optimization across the country. In 2011, a study by Herman compared inorganic fertilizer with Farm Yard Manure (FYM) in maize production in Western Kenya. The study found that inorganic fertilizer produced maize grain yields $68 \%$ higher than Farm Yard Manure (FYM), [13]. The study further pointed out that there was a general decline in soil nutrients and in maize grain yield despite soil fertility management options, with maize leaves at initial silking stage indicating low nutrients below the expected levels. The study studied one factor (maize grain yield) with no considerations of other key treatment factors in maize production. Despite the study attempting to maximize maize grain yield using the chemical fertilizer and FYM, a gap in answering the minimal set of treatment factors for maize production under the two options (N and FYM) and how to mix (blend) was not addressed. The study concluded that the current practice and rate (50 kgha $)$ of Nitrogen $(\mathrm{N})$ was not adequate. This conclusion missed to propose the optimal levels of inputs to maximize the maize yield, the answers on what happens to other factors was omitted in totality, [13].

In Northwest highlands in Ethiopia, Admas in 2015 investigated the effects of combined application of organic and inorganic fertilizer on maize grain yield, [1]. High outcomes (grain yield, dry biomass, plant height, grains per 
comb and cob weight) were witnessed in plots with highest levels $(120 \mathrm{~kg} / \mathrm{ha}, 10$ tons of compost and $15 \mathrm{~kg} / \mathrm{ha}$ of $\mathrm{S})$. The study concluded that high maize grain yield was possible through combined treatments of fertilizer, compost and S. The study recommended the use of an integrated approach (inorganic and organic fertilizer) owing to the benefit of affordability and the improved soil fertility. However, similar to the study by Herman, a single factor (response) approach was adopted leaving other (e.g. Soil Organic Matter (SOM)) and did propose a minimum set of treatment factor to be experimented. In a long-term (18 years) study in Northeast, China, concluded that rotational (maize-maize-soya beans) management combined with FYM had a significant improvement on the soil fertility. The study evaluated the effects of different fertilization and tillage options. The study focused on increasing the overall nitrogen and organic nitrogen. This was an experiment to establish combination of soil fertility options resulting to the best results: a one factor optimization also which did not prescribe the minimum set of experimental treatment factor for optimal results.

Kimetu in 2008 in Western Kenya studied the decrease of Soil Organic Matter (SOC) and the nutrients following continuous cultivation of maize crop. Despite the full (N-120, P-100 and $\mathrm{K}-100 \mathrm{~kg} / \mathrm{ha}$ ) application of the inorganic fertilizer on maize grain yield at different levels into different degraded soils showed that the yields had decreased by $66 \%$ (3.0 ton/ha) over the past 35 years of continuous cultivation and remained low despite the intensive use of the inorganic fertilizer application. Manure as a soil fertility management practice had favorable positive long-term effects on the maize yields as they improved the soil structure in addition to providing extra soil nutrients. The study concluded that addition of organic matter decreased the need to apply inorganic fertilizers. Despite the important findings on the use of organic matter to maintain soil fertility the study failed to address the minimum set of inputs $\left(\mathrm{x}_{\mathrm{i}, \mathrm{s}}\right)$ to maximize the maize grain yield and retention of maximum total microbial population count $\left(\mathrm{y}_{\mathrm{i}^{\prime} \mathrm{s}}\right)$.

Mucheru-Muna in 2013, carried out a two cites trials in different soil fertility to determine the combined effects of organic and mineral fertilizers on maize grain yield, [13]. The study also aimed at determining the economic returns on the different soil management options. Maize grain yield were significantly lower in fields with only mineral fertilizers compared to the combined cases (mineral and organic) with generally low economic returns. Treatments that gave the highest maize grain yield returns did not result to improved soil fertility. The study concluded that there was need for a trade-off between high maize grain yield and soil fertility soil management options a gap whose solution lies with the robust statistical testing and modelling. (Mucheru-Muna, et al., 2013).

Kihanda, Warren and Michemi in 2006 monitored the trends in cereals and legumes grain yields on rotational basis using SOC and soil extractable $\mathrm{P}$ over 13 years under different treatment levels of goat manure $(0,5$ and 10 tons $\mathrm{kg} / \mathrm{ha}),[18]$. The study concluded that grain yields increased and stabilized with addition of manure over 7 consecutive years. Mineral fertilizers had the same trends as the goat manure ( 5 tons ha $)$ that portrayed yield decline at the $9^{\text {th }}$ year of up to about $80 \%$. The study failed to prescribe various optimal set of treatment factors.

\subsection{LTAE on Soil Fertility Studies}

All over the world LTAE have been set-up with an objective of establishing the appropriate methods of soil fertility maintenance. However, some have closed down due to several challenges (low funding among others). LTAE are very expensive, but under the condition of comprehensive and coordinated evaluation they still represent the most costeffective research methods and solutions in agriculture, [6]. There have been a substantial number of LTAEs in Africa addressing a wide range of purposes. The existence of these experiments provides opportunities to investigate the effects of different nutrient management practices on soil fertility and crop yields over time. With the knowledge obtained on the basis of LTAE farmers could double their yields, improve quality of the produce, promote sustainable environmental protection and secure the sufficient human nutrition, [3].

\subsection{Sampled of Key Findings from LTAE}

The LTAE have remarkably contributed to the present knowledge of soil fertility. LTAE have provided valuable scientific knowledge on long-term changes and the results have been applied both by the extension service providers and in environmental regulations. In all LTAE cases it was demonstrated that with Good Agricultural Practices (GAP) the grain yields of the various crops were significantly improved. Blair et al. in their $1^{\text {st }}$ studies that began in 1984 and the $2^{\text {nd }}$ that began in 1990 in Lauchstadt in Germany found that fertilization had a positive increase in the yields. The study further established that continuous tilling fallow resulted in significant decreases in all important soil nutrients and that application of Farm Yard Manure (FYM) could increase SOM and improve soil physical fertility. Using the same data Merbach and Schulz in 2013 established that the first and last decades, crop yields nearly doubled. In unfertilized plots, yields and Nitrogen $(\mathrm{N})$ uptake by crops also increased when comparing first and last decades, [21].

In Saria, Burkina Faso, the twenty years of continuous cultivation without external inputs (the control treatment) depleted Soil Organic Matter (SOM) levels to below 50\% of those under fallow. In Sadore, Niger, yield showed that combining organic and mineral fertilizers had the best results. Application of both crop residues and fertilizer increased millet yield to almost 3 times (from $700 \mathrm{~kg} / \mathrm{ha}$ to 2,000 $\mathrm{kg} / \mathrm{ha}$ ) from the treatment site, [2]. In Kenya, LTAE conducted in Kabete, established that, FYM had longer soil fertility maintainance compared to the chemical fertilizers overtime.

In Embu, LTAE on maize concluded that the average maize grain yields treatments receiving both organic and inorganic nutrient sources recorded the highest yields 
compared to continuous fertilizer application treatments, [17]. In South Africa, the highest maize yields were recorded on plots that were rotated with maize and pigeon pea. Highest maize yields were obtained in the initial year across sites of the trial, which decreased over time.

Results from Burkina Faso in Saria LTAE, observed that fertilizer responses were higher in fertile soils than in degraded soils. In the same experiment, sorghum grain yield increased from about 0.5 tons/ha to over 2.5 tons/ha when manure was combined with mineral fertilizer compared to a maximum yield of 0.6 tons/ha under the no input (control) system.

In Sahelian, West Africa the experiment pointed out that SOM was lost by up to $5 \%$ per annum on sandy soils and around $2 \%$ on better textured soils. LTAE in Africa, occupy crucial element in the processes and functioning of many of the cropping systems in tropical Africa and yield optimization.

The above studies point out to a one dimensional soil fertility maintainance and less use of the robust statistical analysis approaches. It could be pointed out that experiments in agriculture are invariably constrained to be long-term and the primary focus has been only the identification of one factor (minimum set) of interest leaving other factors unattended to which have resulted in a short term conclusions.

\subsection{Determination of Significant Treatment Factors in an Experiment (Screening Experiments)}

A screening design is normally performed in the beginning of an investigation when the experimenter wants to characterize a process. In this case, characterizing translates to determining the main treatment factors and investigates the changes of the response by varying each factor. This identification of the critical process treatment factors can be very useful for later optimization processes because only a subset of the treatment factors have to be considered. In this phase, the process is to identify the main treatment factors other than the interaction effect. Factor screening has played a big role in large experiments with many factors to optimize.

An experiment can have a large number of factors but usually only a handful of these factors are important and significant. A screening experiment employs a design of economical run size to identify the most important factors, [5]. Such experiments are $1^{\text {st }}$-order design fractional factorial designs or Plackett-Burman designs with intensive study of the response surface, typically with fewer factors and over a smaller region. $2^{\mathrm{n}-\mathrm{k}}$ designs are most commonly used for screening stage.

Another useful approach in the identification of key factors is the use of Pareto plots that graphically represents the most important treatment factors in their absolute terms. The plots are weights of the different factors in descending order with less important factors forming the tail of the plot (lower weights). In such plots care is called for as for qualifying a factor that has a significant interaction(s) as in no case that a factors' main effect is rejected and its interaction is qualified.

The goal at this stage (screening) is to find the real important inputs (factors) among the many inputs/output factors that may be changed in a real experiment. Real-world processes are driven by only a few factors, the others being relatively unimportant. With screening designs, responses are taken only for a small fraction of the total possible combinations to reduce the number of runs and hence cost, [31].

Specialized designs require screening when number of factors is too large for even a highly fractionated design, [15]. Various screening analyses can be utilized with the most conventional method based on main effects estimation or the Analysis of Variance (ANOVA). A factor is identified as important if its main effects are significant, [5]. Analysis of the main-effect may not be appropriate if the interactions are large enough to bias the main effect estimation. In such cases therefore, a more elaborate analysis such as the Bayesian method. The study approach was that in each subset of treatment factors were associated with a linear model that contained main effects and two-factor interactions for the factors. By comparing the posterior probabilities of these models, the important factors were identified and isolated.

Table 1. Evaluation Criteria for Factor Screening.

\begin{tabular}{ll}
\hline Analysis Step & Design Property \\
\hline Factor Screening & Orthogonality maximum number of factors \\
Projection & Eligibility projection \\
RSM & Estimation of efficiency \\
\hline
\end{tabular}

According to Cheng and $\mathrm{Wu}$, in factor screening, a good design should be able to accommodate a large number of treatment factors with relatively few runs and still possess orthogonality property. Orthogonal designs prevent experiments from accidentally confusing the effects of two different factors, [31]. A projected design obtained after stage 1 is said to be eligible if it is a second-order design, otherwise it is said to be ineligible. Pareto graphs are also important elements in the evaluation of the significant factors and undertaking model fit.

\section{Method}

\subsection{Determination of the Most Significant Treatments for Maize Yield and Total Microbial Population}

To achieve the objective the initial step involved analysis of all the six (6) treatment factors (Control, R, FYM, $\mathrm{FYM}_{2}$, $\mathrm{N}_{1} \mathrm{P}_{1}$ and $\mathrm{N}_{2} \mathrm{P}_{2}$ ) that were distributed into 4 blocks (Block I, II, III and IV) (Table 2). This enabled screening of the most 
important treatment factors to form inputs for robust experimental stage and experimentation purpose.

It's normal for a study/system to have a large number of treatment factors but usually only a handful of these are important and significant. All factors are considered important thus the need to evaluate them and arrive at a minimum set. This is due to the fact that experiments are usually expensive to plan, repeat and also to avoid leaving out important factors in the early analysis stage the phase is key. The screening phase analysis was based on a $1^{\text {st }}$ - order regression model followed by a more intensive study of the response surface with fewer factors and over a smaller region based on second-order design (for testing significant interaction factors).

\subsection{Principals in the Determination of Significant Treatment Factors}

These included:-

1. Considering the most important treatment factors;

2. Utilizing/using the most dominant treatment factors with great impact on both response factors;

3. Time taken for undertaking the various treatment levels into consideration (some factors may require considerable amount of time to evaluate);

4. Using the $1^{\text {st }}$-order model;

5. Consultation with the agricultural specialists/experts on the most significant factors and

6. Consideration of the main effects (not interactions) for possible retention of the candidate treatment factors.

\subsection{Computation of the Response Variables ( $Y_{1}$ and $\left.Y_{2}\right)$}

The primary response variable; maize grain yield $\left(\mathrm{y}_{1}\right)$ was derived from the yield achieved from two rain seasons (Short Rain (SR) and Long Rain (LR) in 2001/2002. The variable was measured in $\mathrm{kgha}^{-1}$ over the two seasons. To get the actual variable to be used in the regression, yield was averaged over the two seasons. The yield from each of the six (6) treatments and four blocks are presented. The total microbial population count $\left(\mathrm{y}_{2}\right)$ was computed by summing the counts from the four microbial elements (bacteria, fungi, actinomycetes and rhizobia) across the four blocks over the two seasons.

\subsection{Exploratory Data Analysis (EDA)}

In determining of the most significant factors Exploratory Data Analysis (EDA) was the first procedure that was undertaken. EDA techniques were undertaken to unravel the structure and the pattern of the study data. In this stage graphical representation of the various factors and descriptive analysis were done.

\subsection{Important Minimum set of Treatment Factors for Maize LTEA}

Both response variables (maize yield $\left(\mathrm{y}_{1}\right)$ and total microbial population $\left(\mathrm{y}_{2}\right)$ were fitted with a $1^{\text {st }}$-order linear regression models upon which the variable selection procedures were applied. The two main approaches applied in the variable selection included: the all possible regressions approach and automatic methods. The all possible regressions approach considers all possible subsets of the pool of explanatory variables. The model that best fitted the data according to some criteria that include, adjusted $\mathrm{R}^{2}$, Akaike Information Criterion (AIC) and Bayesian Information Criterion (BIC).

The following approaches that significantly helped in the search for the bets set of factors was the use of;

a. Forward selection,

b. Backward elimination and

c. Stepwise regression

To determine factors that significantly explained maize grain yield $\left(\mathrm{y}_{1}\right)$, the study used a $1^{\text {st- }}$ order model. This included considering the full model for all the factors, a procedure that was followed by the Pareto charts for filtering of the significant regression factor weights.

\subsection{Model Diagnostics}

The models for the screened factors and the final model were subjected to model diagnostics. These included statistical tools and methods for determining whether the regression model fitted the experimental data adequately (aspects of parsimony taken into account). The procedures depended however on whether the resultant model was a Linear Models (LM) fitted using the Least Squares Methods (LSM) or a Generalized Linear Model (GLM) was fitted using the Maximum Likelihood Estimation (MLE).

\subsection{Study Data}

The overall resultant data was obtained from a Randomized Complete Block Design (RCBD) with 18 treatments with four replicates for a period of 25 years (1976 - 2001) which formed the preliminary analysis for initial literature justification. A further screening and optimization purpose the 2002 sampled data was used. The 2002 data set had maize grain yield and total microbial population count results measured during the SR and LR. In this data set only six (6) factors were measured.

For the purpose of this study, both the response and process/input variables are reviewed. All the six (commonly used practices by farmers) factors were analyzed to determine the most significant treatment factors.

\section{Results}

EDA techniques were undertaken to unravel the data structure and pattern.

Box plots (Figure 1-2) revealed significant differences over the two seasons across the treatment factors for maize grain yield $(\mathrm{kg} / \mathrm{ha})$ and total microbial population count. This implied that the treatments had varied impacts for the two response factors. This was mainly due to the fact that LTEA are rain depended (uncontrolled input factors) presenting varying trends over the same periods as depicted in Figure 3. 
In the Figure 3, the three key weather patterns confirmed the expected and results of maize yield in the two seasons. These could also be explained by the ongoing climate changes affected the crops not only in maize but also other cereals. The results compare well with the reported national production data that portrayed similar trends $(1963-2014)$ as provided in the Table 3. Maize grain yields and the treatments assumed a bimodal distributions and minimal degree of possible linearity is depicted. This could be explained by the serial correlation between the $\mathrm{y}_{1, \mathrm{t}}$ and $\mathrm{y}_{1, \mathrm{t}-1}$ for maize grain yield in the consecutive years and also seasonality components. These trends and findings are in agreement with previous studies by Kibunja in 2007, [17] and Bationo in 2012, [2], that established declining trend in maize grain yields under various soil management options in NARL and in Embu respectively.

The blocking effect had no significant difference in maize grain yield over time. The same results of declining yield were also evident across other LTEA in the region, e.g. in Saria in Burkina Faso. Globally, LTEA in Lauchstadt, Germany arrived at similar conclusions of declining yields.

\subsection{Descriptive Analysis for the Maize Yield and Total Microbial Population}

There was a notable significant differences ( $p$-value $<0.05$ ) in the total microbial population, with the highest microbial population found in $\mathrm{FYM}_{1}+\mathrm{R}$ at $4.9 \times 10^{6}, \mathrm{FYM}_{1}$ at $4.1 \times 10^{6}$ and the $3^{\text {rd }}$ was the $\mathrm{N}_{1} \mathrm{P}_{1}+\mathrm{FYM}_{1}$ at $3.4 \times 10^{6}$. The least microbial population count was in treatment with NIL+R at $1.3 \times 10^{6}$ (Table 5). The highest maize grain yield were registered in $\mathrm{N}_{1} \mathrm{P}_{1}+\mathrm{FYM}_{1}$ at $3.9 \times 10^{3}, \mathrm{~N}_{1} \mathrm{P}_{1}+\mathrm{FYM}_{1}+\mathrm{R}$ at $3.7 \times 10^{3}$ and the least on the top 3 treatment factors were $\mathrm{FYM}_{1}+\mathrm{R}$ at $3.4 \times 10^{3}$ (p-value $\left.<0.05\right)$. The least maize yields were achieved in the NIL (control) categories at $1.9 \times 10^{3}$ (Table 6-7).

These findings give two opposite pointer for the two treatment factors selections and conclusive identification. For the total microbial population it's explained through the use of organic soil management options while the increase in maize grain yield was favored by the use of increased application of inorganic soil management treatment options. This could be portrayed through the Table 8 .

\subsection{Impact of the Treatment Factors on the Dependent Variables}

Maize grain yield of higher than $3.0 \times 10^{3}$ was marked as increase $=$ " $"$, maize yield of $2.0 \times 10^{3}$ was coded as medium represented as "=" and for maize yield $<2.0 \times 10^{3}$ was denoted as " $\Downarrow "$. Similarly, for total microbial population count of higher than $4.0 \times 10^{5}$ was marked as increase $=" \Uparrow "$, microbial population count of $2.0 \times 10^{5}$ was coded as medium represented as "=" and for those microbial population count $<$ $2.0 \times 10^{5}$ was denoted as " $"$ ". The last column in Table 7, is a comparative analysis of the treatment in questions as " $\sqrt{ }$ " and $" \otimes "$ for contradictory directions.

\subsection{Most Significant Treatment Factors for the Maize Grain Yield $\left(Y_{1}\right)$}

From the regression analysis (Table 6) three factors levels were significant for maize yield $\mathrm{N}_{1} \mathrm{P}_{1}+\mathrm{FYM}_{1}\left(\mathrm{x}_{1}\right)$, NIL and $\mathrm{NIL}+\mathrm{R}$ and $\mathrm{FYM}_{1}$ (in the intercept) all with p-value $<0.001$, $\mathrm{R}^{2}=96.4 \%$ and adjusted $\mathrm{R}^{2}=94.6 \%$. However, treatments with NIL (controls) had a negative (-ve) influence on the maize grain yield. The treatments were also significant ( $\mathrm{p}$ value $<0.001$ ) while that of blocks was not statistically significant. The intercepts was large enough to be ignored and therefore it was retained for modeling the maize grain yield. The blocks effects were not significant which was due to their insignificance from the initial descriptive plots. This was an encouraging result as blocks were only intended for local control and further random error.

The largest positive effects on the maize grain yields were realized with $\mathrm{N}_{1} \mathrm{P}_{1}+\mathrm{FYM}_{1}, \mathrm{~N}_{1} \mathrm{P}_{1}+\mathrm{FYM}_{1}+\mathrm{R}$ and $\mathrm{FYM}_{1}+\mathrm{R}$ treatments while the greatest negative effects were from NIL, $\mathrm{NIL}+\mathrm{R}$ treatments. This is a clear indication that the combination of chemical fertilizers and the FYM had better yields for maize.

To achieve this, two statistical criteria were employed that included the Adjusted $\mathrm{R}^{2}$ and BIC for all possible regressions approaches. The study first established the all possible regressions approach followed by the automatic methods. To ensure that the treatments factors were identified in a more robust away, further automatic approach was employed. In this case the study used the three factor selection procedure, forward, backward and both selection procedures that confirmed similar results for the full model as indicated in Table 9. To undertake this procedure, all the full models using the three procedures gave the least AIC of 317.65 confirming that treatment factors were important. This was further confirmed through the Pareto plot (Figure 4).

Under this section, the study evaluated the model adequacy. This included the plot of the actual verses the fitted values The model portrays degree of adequacy. In the normality check, the quantile-quantile plot is expected to be along a 45 degree line. For homoscedasticity, the plots of the residuals against the predicted values were done to get a sense of the spread along the regression line. Further, diagnostics were performed using the global validation of linear model assumptions as well separate evaluations of skewness, kurtosis, and heteroscedasticity.

The model failed to meet the only one criterion on kurtosis with all the other key model diagnostic criteria met. These included global statistics (5.3), skewness (0.15) and heteroscedasticity at 0.11 . These results made the passage of the model with 4 out of the 5 set criteria satisfied.

\subsection{Most Significant Factors for Total Microbial Population Count (y $y_{2}$}

To determine the significant treatment factors that explained the total microbial population count $\left(\mathrm{y}_{2}\right)$, the sum of population count for bacteria, fungi, actinomycetes and rhizobia was used. The $1^{\text {st }}$-order model for the total microbial population count 
did not reflect significant ( $p>0.05$ ). This led to the undertaking of a full model, normally proposed in such cases to get the significance in higher levels models (Table 10).

\subsection{Joint Identifying the Most Significant Treatments for Maize Yield and Total Microbial Population (y $y_{1}$ and $\left.y_{2}\right)$}

From the two $1^{\text {st }}$-order models presented selection a parsimonious set of treatment factors were identified both the responses. From the above analysis and the Pareto charts only the single treatment factors with most significant values were isolated. Considering the significant factors and impact of the factors (Table 12) and through informed consultation with the LTEA experts on the commonly used practices by small-scale farmer and also due to its significance size, the $\mathrm{FYM}_{1}+\mathrm{N}_{1} \mathrm{P}_{1}$ treatment factors was identified for undertaking the experimental undertakings of maize grain and microbial counts. These include combination of the FYM (organicmanure application of $5 \mathrm{ton} / \mathrm{Ha}$ "boma" manure (about $75 \mathrm{~kg}$ $\mathrm{N}$ and $20 \mathrm{~kg} \mathrm{P}$ ) and the use $\mathrm{N}_{1} \mathrm{P}_{1}$ (chemical fertilizers $-\mathrm{N}_{1} 60$ $\mathrm{kg} \mathrm{N} / \mathrm{ha}$ as Calcium Ammonium Nitrate (CAN), $\mathrm{P}_{1}-26.4$ $\mathrm{kg} / \mathrm{ha} \mathrm{P}$ as Triple Superphosphate (TSP).

\section{Discussion}

The national maize yields from the administrative records presented similar mixed trend as compared to the LTEA, with lows of ( 0.33 tons/ha) and highs of ( 2.3 tons/ha) between 1964-2014. The trend revealed the declining trend in the years when it is expected to register considerable higher yields as the demand for much crop produce to bridge the gap between production and the increasing human population.

Most important treatment factors for explaining the two dependent factors, 2002 data from the LTEA was used with only two dependent factors being significant. A few screened variables were identified in explaining the outcome variables $\left(\mathrm{y}_{1}\right.$ and $\left.\mathrm{y}_{2}\right)$. Only interaction between, NIL: Block-II and $\mathrm{FYM}_{1}$ : R: Block-II turned significant in the full model. This indicated that their main factors need to be considered in the optimization stage as primary treatment factors. This implies that NIL (control) and $\mathrm{FYM}_{1}+\mathrm{R}$ were important. R-square improved from $24 \%$ to $69 \%$ from the reduced model to the full model $\left(2^{\text {nd }}-\right.$ order $)$.

\section{Conclusion}

It was evident that the maize grain yield from the LTEA were experiencing yields decline over the last years despite the continuous soil management option practices. The maize grain yields had declined to lows of about $2,100 \mathrm{~kg} / \mathrm{ha}$ in some treatments/soil management options. This calls for an integrated reversal approach in the retaintion of soil fertility. This point to a possible conclusion that the current operating soil fertility options are not optimal for the future soil fertility retention and for sustained maize yields.

Two treatment factors were isolated during the screening phase as the most significant and important treatment factors from a possible range of input and controllable factors. These were farm yard manure $\left(\mathrm{FYM}_{1}\right)$ and chemical fertilizers at level $\mathrm{N}_{1} \mathrm{P}_{1}$ at their lower levels. These two treatment factors had significantly explained the maize grain yield and total microbial population count. These two treatment factors were important in for ensuring the optimal maize yields while retaining the required threshold for total microbial population.

\section{Appendices}

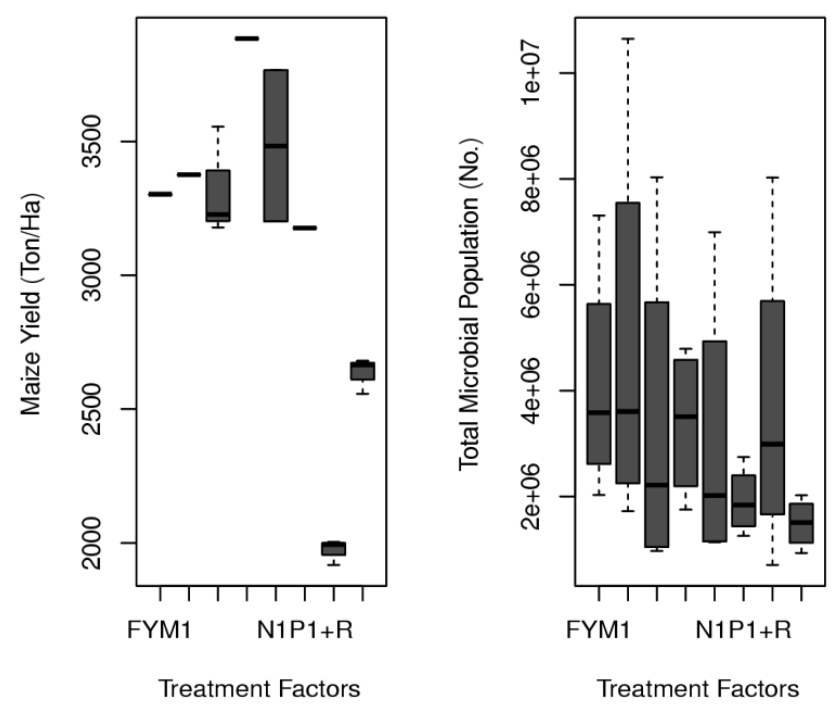

Figure 1. Box Plot for Maize Grain Yield and Total Microbial Population by Treatment.
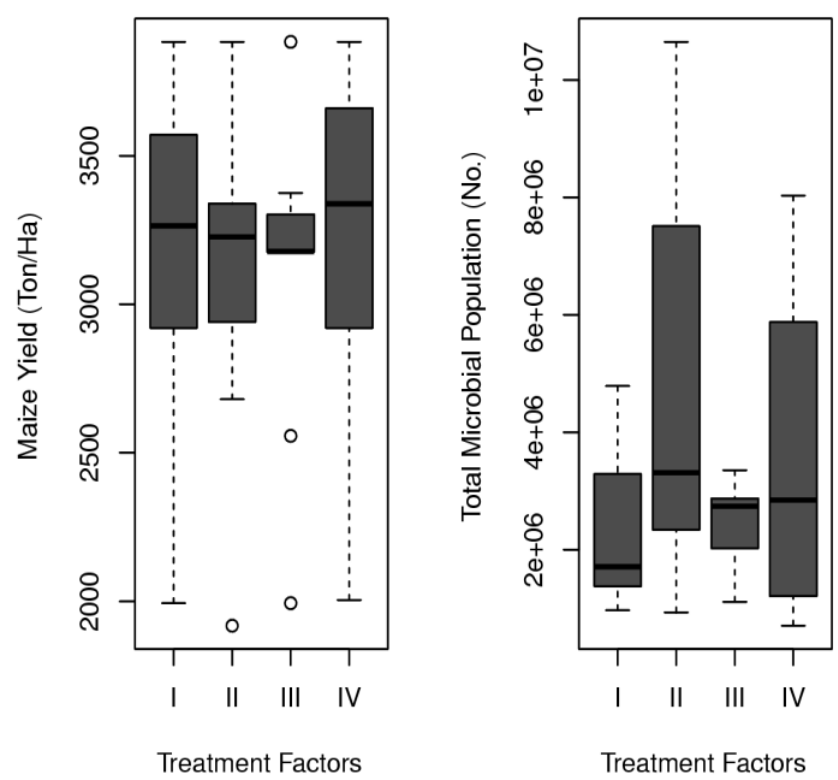

Figure 2. Box Plot for Maize Grain Yield and Total Microbial Population by Blocks. 
Temparature

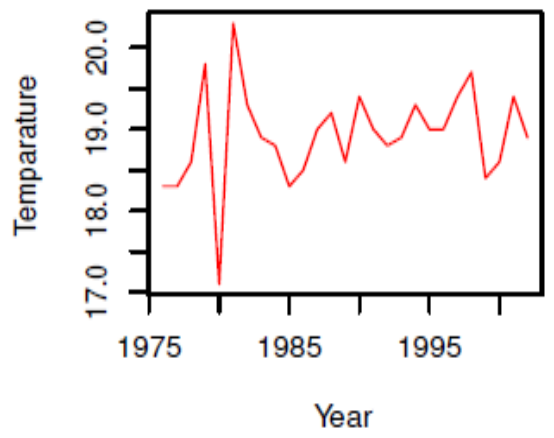

Evaporation

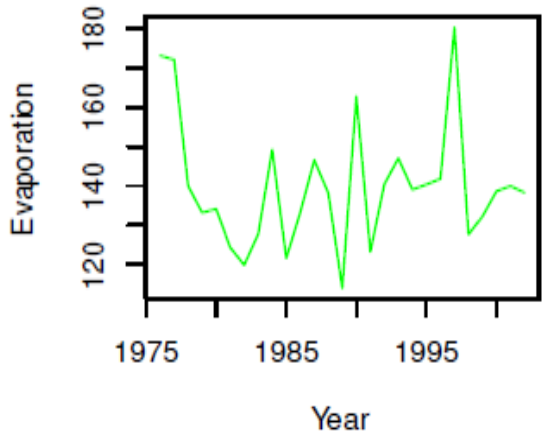

Rainfall

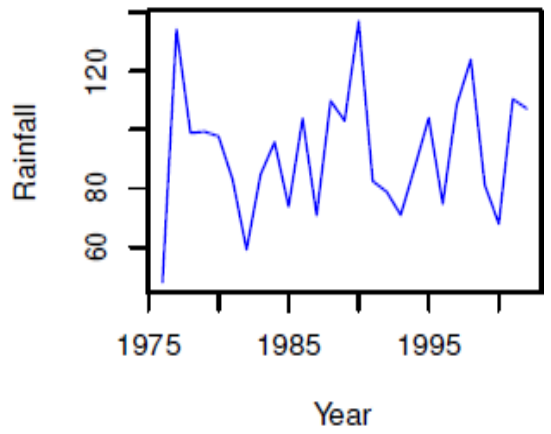

Figure 3. Trend in Weather Pattern Parameters.

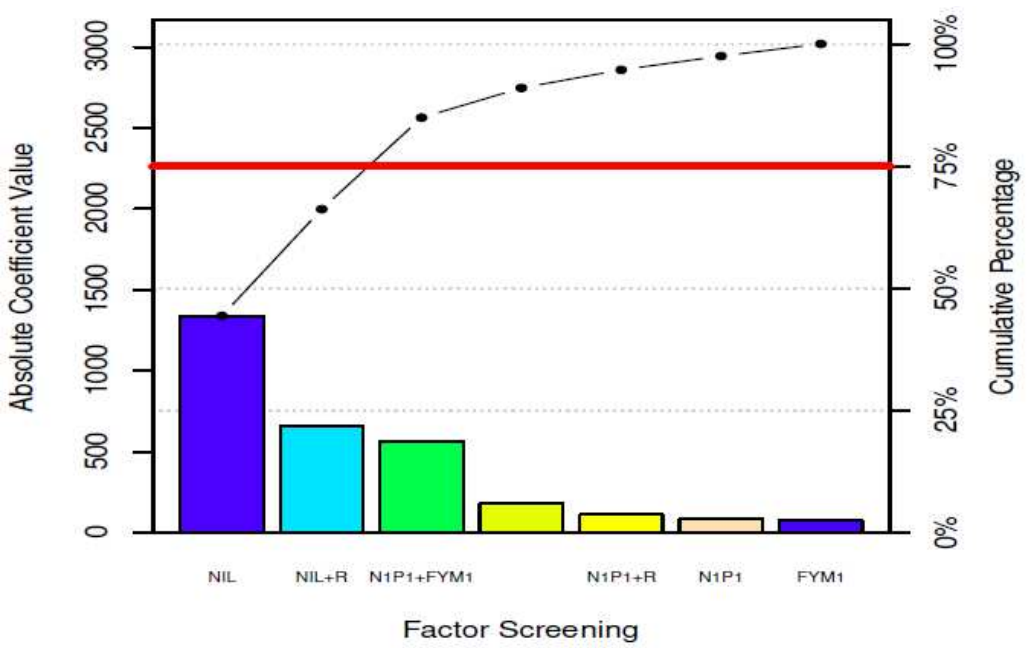

Figure 4. Maize Yield (y1) Factors Pareto Chart.

Table 2. Treatments factors.

\begin{tabular}{|c|c|c|c|c|}
\hline Variable & Variable Type & Description & Derivation of the Variable & Optimization Goal \\
\hline Yield (y1) & Response & Achieved yield & $\begin{array}{l}\text { Yield from the Soil } \\
\text { Management }\end{array}$ & Maximum \\
\hline Microbial Population (y2) & Response & Bacteria, Rhizobia, Fungi, Actinomycetes & Total Microbes & Maximum \\
\hline Control + R (x2) & Dependent & Controlled inputs & & \\
\hline FYM1+R (x3) & Dependent & Controlled inputs & & \\
\hline $\mathrm{N} 1 \mathrm{P} 1(\mathrm{x} 4)$ & Dependent & Controlled inputs & & \\
\hline N1P1+FYM1(x6) & Dependent & Controlled inputs & & \\
\hline $\mathrm{N} 1 \mathrm{P} 1+\mathrm{FYM} 1+\mathrm{R}(\mathrm{x} 7)$ & Dependent & Controlled inputs & & \\
\hline
\end{tabular}


Table 3. National 10 Year Maize Yield $\left(y_{1}\right)$ Average.

\begin{tabular}{ll}
\hline Years & Yield (ton/Ha) \\
\hline $1964-74$ & 0.74 \\
$1975-84$ & 1.49 \\
$1985-94$ & 1.80 \\
$1995-04$ & 1.59 \\
$2005-15$ & 1.62 \\
\hline
\end{tabular}

Table 4. Trend in National Maize Grain Yield ( $\left.y_{1}\right), 1963-2014$.

\begin{tabular}{|c|c|c|c|}
\hline Year & Area (Ha) & Production (Tons) & Yield (Tons/Ha) \\
\hline 1964 & 701300 & 229500 & 0.33 \\
\hline 1965 & 454000 & 187700 & 0.41 \\
\hline 1966 & 346000 & 295700 & 0.85 \\
\hline 1967 & 447700 & 403200 & 0.9 \\
\hline 1968 & 829300 & 511200 & 0.62 \\
\hline 1969 & 939400 & 619200 & 0.66 \\
\hline 1970 & 943400 & 727200 & 0.77 \\
\hline 1971 & 974700 & 835200 & 0.86 \\
\hline 1972 & 1043000 & 943200 & 0.9 \\
\hline 1973 & 1211600 & 1051200 & 0.87 \\
\hline 1974 & 1151300 & 1159200 & 1.01 \\
\hline 1975 & 1161800 & 1267200 & 1.09 \\
\hline 1976 & 1190900 & 1375200 & 1.15 \\
\hline 1977 & 1215800 & 1597100 & 1.31 \\
\hline 1978 & 1246700 & 1671400 & 1.34 \\
\hline 1979 & 1282100 & 1620000 & 1.26 \\
\hline 1980 & 1322700 & 1606500 & 1.21 \\
\hline 1981 & 1364900 & 1888300 & 1.38 \\
\hline 1982 & 1120000 & 2560000 & 2.29 \\
\hline 1983 & 1208000 & 2450100 & 2.03 \\
\hline 1984 & 1236000 & 2214800 & 1.79 \\
\hline 1985 & 1230000 & 1500000 & 1.22 \\
\hline 1986 & 1370000 & 2440300 & 1.78 \\
\hline 1987 & 1430000 & 2870000 & 2.01 \\
\hline 1988 & 1440000 & 2400000 & 1.67 \\
\hline 1989 & 1420000 & 3140000 & 2.21 \\
\hline 1990 & 1460000 & 3030000 & 2.08 \\
\hline 1991 & 1300000 & 2890000 & 2.22 \\
\hline 1992 & 1310000 & 2400000 & 1.83 \\
\hline 1993 & 1407000 & 2430000 & 1.73 \\
\hline 1994 & 1343500 & 1755000 & 1.31 \\
\hline 1995 & 1500000 & 3060000 & 2.04 \\
\hline 1996 & 1438700 & 2698900 & 1.88 \\
\hline 1997 & 1489000 & 2160000 & 1.45 \\
\hline 1998 & 1504800 & 2214000 & 1.47 \\
\hline 1999 & 1475700 & 2464100 & 1.67 \\
\hline 2000 & 1567200 & 2322100 & 1.48 \\
\hline 2001 & 1500000 & 2160000 & 1.44 \\
\hline 2002 & 1592320 & 2411000 & 1.51 \\
\hline 2003 & 1670910 & 2713560 & 1.62 \\
\hline 2004 & 1819820 & 2454930 & 1.35 \\
\hline 2005 & 1760620 & 2918160 & 1.66 \\
\hline 2006 & 1888190 & 3247780 & 1.72 \\
\hline 2007 & 1615304 & 2928800 & 1.81 \\
\hline 2008 & 1793800 & 2367000 & 1.32 \\
\hline 2009 & 1885000 & 2443000 & 1.3 \\
\hline 2010 & 2008000 & 3465000 & 1.73 \\
\hline 2011 & 2132000 & 3377000 & 1.58 \\
\hline 2012 & 2159000 & 3766000 & 1.74 \\
\hline 2013 & 2123138 & 3592688 & 1.69 \\
\hline 2014 & 2116141 & 3513171 & 1.66 \\
\hline
\end{tabular}


Table 5. Mean Maize Grain Yield by Treatment and Block.

\begin{tabular}{|c|c|}
\hline Treatment/Block & Maize Yield (kg/Ha) \\
\hline $\mathrm{FYM}_{1}$ & 3,302 \\
\hline $\mathrm{FYM}_{1}+\mathrm{R}$ & 3,375 \\
\hline $\mathrm{N}_{1} \mathrm{P}_{1}$ & 3,226 \\
\hline $\mathrm{N}_{1} \mathrm{P}_{1}+\mathrm{FYM}_{1}$ & 3,883 \\
\hline $\mathrm{N}_{1} \mathrm{P}_{1}+\mathrm{FYM}_{1}+\mathrm{R}$ & 3,696 \\
\hline $\mathrm{N}_{1} \mathrm{P}_{1}+\mathrm{R}$ & 3,176 \\
\hline NIL & 1,994 \\
\hline $\mathrm{NIL}+\mathrm{R}$ & 2,665 \\
\hline Block I & 3,099 \\
\hline Block II & 3,308 \\
\hline Block III & 3,224 \\
\hline Block IV & 3,092 \\
\hline
\end{tabular}

Table 6. Model 1 for Maize Yield ( $\left.y_{1}\right)$.

\begin{tabular}{lllll}
\hline Parameter & Estimate & se & t-value & p-value \\
\hline Intercept & $3,302.0$ & 130.1 & 25.4 & $<0.001$ \\
FYM1+R & 74.7 & 99.74 & 0.75 & 0.4621 \\
N1P1 & 8.5 & 99.74 & 0.09 & 0.9329 \\
N1P1+FYM1 & 565.0 & 99.74 & 5.66 & $<0.001$ \\
N1P1+FYM1+R & 182.7 & 99.74 & 1.83 & 0.081 \\
N1P1+R & $(111.7)$ & 99.75 & -1.12 & 0.275 \\
NIL & $(1,340.2)$ & 99.74 & -13.44 & $<0.001$ \\
NIL+R & $(658.5)$ & 99.74 & -6.6 & $<0.001$ \\
Block II & $(6.9)$ & 153.9 & -0.04 & 0.964 \\
Block III & $(57.0)$ & 154.1 & -0.37 & 0.715 \\
Block IV & 63.9 & 154.1 & 0.41 & 0.683 \\
\hline
\end{tabular}

Table 7. Mean Total Microbial Population by Treatment and Block.

\begin{tabular}{llllll}
\hline Treatment/Block & Bacteria & Fungi & Actinomycetes & Rhizobia & Total (Count) \\
\hline FYM $_{1}+\mathrm{R}$ & $4,778,125$ & 30,346 & 30,454 & 58,481 & $4,897,406$ \\
$\mathrm{FYM}_{1}$ & $4,027,875$ & 19,634 & 18,213 & 60,651 & $4,126,372$ \\
$\mathrm{~N}_{1} \mathrm{P}_{1}+\mathrm{FYM}$ & & 26,052 & 48,556 & 88,941 & $3,391,924$ \\
Block IV & $3,228,375$ & 19,365 & 22,491 & 33,317 & $3,162,690$ \\
Block II & $3,087,517$ & 24,101 & 24,866 & 34,373 & $2,789,740$ \\
Block I & $2,706,400$ & 23,647 & 30,820 & 108,498 & $2,596,782$ \\
Block III & $2,433,818$ & 20,466 & 22,685 & 33,832 & $2,405,955$ \\
NIL & $2,328,971$ & 19,195 & 24,844 & 32,961 & $2,307,187$ \\
$\mathrm{~N}_{1} \mathrm{P}_{1}$ & $2,230,188$ & 16,791 & 13,703 & 37,344 & $2,063,837$ \\
$\mathrm{~N}_{1} \mathrm{P}_{1}+\mathrm{R}$ & $1,996,000$ & 21,348 & 9,289 & 93,694 & $1,921,018$ \\
$\mathrm{~N}_{1} \mathrm{P}_{1}+\mathrm{FYM}+\mathrm{R}$ & $1,796,688$ & 20,744 & 41,313 & 84,625 & $1,624,744$ \\
$\mathrm{NIL}_{1}+\mathrm{R}$ & $1,478,063$ & 20,914 & 19,855 & 19,032 & $1,291,239$ \\
\hline
\end{tabular}

Table 8. Impact of the Treatments on the Dependent Variables $\left(y_{1}\right.$ and $\left.y_{2}\right)$.

\begin{tabular}{llll}
\hline Treatment & Maize Yield & Microbial Population & Comment \\
\hline $\mathrm{FYM}_{1}$ & $\Uparrow$ & $\Uparrow$ & $\sqrt{ }$ \\
$\mathrm{FYM}_{1}+\mathrm{R}$ & $\Uparrow$ & $\Uparrow$ & $\sqrt{ }$ \\
$\mathrm{N}_{1} \mathrm{P}_{1}$ & $\Uparrow$ & $=$ & $\sqrt{ }$ \\
$\mathrm{N}_{1} \mathrm{P}_{1}+\mathrm{FYM}_{1}$ & $\Uparrow$ & $\Uparrow$ & $\otimes$ \\
$\mathrm{N}_{1} \mathrm{P}_{1}+\mathrm{FYM}+\mathrm{R}$ & $\Uparrow$ & $\Downarrow$ & $\otimes$ \\
$\mathrm{N}_{1} \mathrm{P}_{1}+\mathrm{R}$ & $\Uparrow$ & $\Downarrow$ & $\otimes$ \\
$\mathrm{NIL}$ & $\Downarrow$ & $=$ & $\otimes$ \\
$\mathrm{NIL}+\mathrm{R}$ & $=$ & $\Downarrow$ & $\otimes$ \\
\hline
\end{tabular}


Table 9. Model Selection Procedure for Maize Grain Yield $\left(y_{1}\right)$.

\begin{tabular}{llll}
\hline Model & Factors & AIC & Procure used \\
\hline 1 & 1 & 406.65 & Forward \\
2 & Treatment & 319.87 & Backward \\
3 & Treatment + Blocks & 317.65 & \\
1 & Treatment + Blocks & 317.65 & Stepwise \\
2 & 1 & 406.65 & 319.87 \\
\hline
\end{tabular}

Table 10. Model for Treatment Factors for Microbial Population ( $\left.y_{2}\right)$.

\begin{tabular}{lllll}
\hline Parameter & Estimate & se & t value & p value \\
\hline Intercept & 3966945 & 2621551 & 1.51 & 0.29 \\
FYM1+R & 583301.9 & 2009380 & -0.3 & 0.145 \\
N1P1 & -602308 & 2009662 & -0.43 & 0.767 \\
N1P1+FYM1 & -870015 & 2009380 & -0.63 & 0.669 \\
N1P1+FYM1+R & -1271215 & 2009380 & -1.02 & 0.534 \\
N1P1+R & -2041483 & 2009662 & -0.29 & 0.321 \\
NIL & -583133 & 2009380 & -1.4 & 0.775 \\
NIL+R & -2818243 & 2009380 & 0.24 & 0.175 \\
Block II & 750926.6 & 3101860 & -0.21 \\
Block III & -655484 & 3104774 & 0.17 \\
Block IV & 542267.8 & 3104774 & 0.811 \\
\hline
\end{tabular}

Table 11. Full Model 2 Treatment Factors for Microbial Population ( $\left.y_{2}\right)$.

\begin{tabular}{|c|c|c|c|c|}
\hline Parameter & Estimate & se & t-value & p-value \\
\hline Intercept & $3,966,945.0$ & $2,911,982.5$ & 1.4 & 0.215 \\
\hline FYM1+R & $(2,859,536.0)$ & $4,118,165.1$ & $(0.7)$ & 0.510 \\
\hline N1P1 & $72,679.0$ & $4,118,165.1$ & 0.2 & 0.866 \\
\hline N1P1+FYM1 & $(2,725,349.5)$ & $3,566,435.6$ & $(0.8)$ & 0.470 \\
\hline $\mathrm{N} 1 \mathrm{P} 1+\mathrm{FYM} 1+\mathrm{R}$ & $(6,144,462.0)$ & $4,118,165.1$ & $(1.5)$ & 0.179 \\
\hline $\mathrm{N} 1 \mathrm{P} 1+\mathrm{R}$ & $(6,047,450.0)$ & $4,118,165.1$ & $(1.5)$ & 0.185 \\
\hline NIL & $(5,641,030.0)$ & $3,566,435.6$ & $(1.6)$ & 0.158 \\
\hline $\mathrm{NIL}+\mathrm{R}$ & $(5,986,798.0)$ & $4,118,165.1$ & $(1.5)$ & 0.189 \\
\hline Block II & $(1,933,865.0)$ & $4,118,165.1$ & $(0.5)$ & 0.653 \\
\hline Block III & $(769,801.0)$ & $4,118,165.1$ & $(0.2)$ & 0.857 \\
\hline Block IV & $3,341,376.0$ & $4,118,165.1$ & 0.8 & 0.444 \\
\hline FYM1+R:Block II & $7,013,595.0$ & $5,447,820.4$ & 1.3 & $0.024 *$ \\
\hline N1P1+ Block II & $558,494.0$ & $5,823,964.9$ & 0.1 & 0.926 \\
\hline N1P1+FYM1:Block II & $3,340,852.5$ & $5,447,820.4$ & 0.6 & 0.559 \\
\hline N1P1+FYM1+R:Block II & $8,176,981.5$ & $5,447,820.4$ & 1.5 & 0.177 \\
\hline N1P1+R:Block II & $5,637,904.0$ & $5,823,964.9$ & 1.0 & 0.365 \\
\hline NIL:Block II & $116,326,650.0$ & $5,447,820.4$ & 2.1 & $0.07 *$ \\
\hline NIL+R:Block II & $5,272,073.5$ & $5,447,820.4$ & 1.0 & 0.365 \\
\hline FYM1+R:Block III & $2,428,955.0$ & $5,823,964.9$ & 0.4 & 0.689 \\
\hline N1P1:Block III & $(2,874,062.0)$ & $5,447,820.4$ & $(0.5)$ & 0.614 \\
\hline N1P1+FYM1:Block III & $1,281,375.5$ & $5,447,820.4$ & 0.2 & 0.821 \\
\hline N1P1+FYM1+R:Block III & $5,823,818.0$ & $5,823,964.9$ & 1.0 & 0.351 \\
\hline N1P1+R:Block III & $5,250,139.5$ & $5,447,820.4$ & 1.0 & 0.367 \\
\hline NIL: Block III & $5,799,829.0$ & $5,447,820.4$ & 1.1 & 0.322 \\
\hline NIL+R:Block III & $4,814,864.0$ & $5,823,964.0$ & 0.8 & 0.436 \\
\hline
\end{tabular}

Table 12. Description of the Treatment Factors.

\begin{tabular}{|c|c|c|c|c|c|}
\hline Factor & N (kg/ha) & P (kg/ha) & Total & Ratio (N:P) & Product \\
\hline 1FYM1 & 75 & 20 & 95 & 3.75 & Boma Manure \\
\hline N1P1 & 60 & 26.4 & 86.4 & 2.3 & CAN, TSP \\
\hline
\end{tabular}




\section{References}

[1] Admas, H., Gebrekiadan, H., Bedadi, B., \& Adgo, E. (2015). Effects of organic and inorganic fertilizers on yield and yield components of maize at Wujiraba Watershed, Northwestern Highlands of Ethiopia. American journal of plant nutrition and fertilization technology, 5(1), 1-15.

[2] Bationo, A., Kihara, J., Vanlauwe, B., Waswa, B., Adolwa, I., \& Saidou, K. (2012). Lesson learned from long-term soil fertility management experiments in Africa. Springer Doordrecht Heidelberg New York London.

[3] Blair, N., Faulkner, R. D., Till, A. R., Korschen, M., \& Schulz, E. (2006). Long-term management impacts on soil C, N and physcial fertility. Soil \& Tillage Research, 191, 39-47.

[4] Chelule, J. C. (2012). Application of response surface methodlogy in modeling a farm production process in the presence of randon-effect (Unpublished PhD Thesis). Nairobi: Jomo Kenyatta University of Agriculture and Technology.

[5] Cheng, S.-W., \& Wu, C. F. (2001). Factor screening and response surface exploration. Statistica Sinaca, 553-604.

[6] Dick, P. R. (1992). A review of long-term effects of agricultural systems on soil biochemical and microbial parameters. Agriculture, Ecosystems \& Environment, 40, 2536.

[7] Food and Agricture Organization for United Nation. (2012). The state of food insecurity in the world. Rome: United Nations.

[8] Food and Agriculture for United Nation. (2014). The state of food insecurity in the world. Rome: United Nation.

[9] Food and Agriculture Organization for United Nation. (2013). The state of food and agriculture. Rome: United Nation.

[10] Food and Agriculture Organization of the United Nation. (2015). The State of Food and Agriculture Report 2015: Social protection and agriculture: breaking the cycle of rural poverty. Rome: United Nation.

[11] George, E. P., Hunter, J. S., \& Hunter, W. G. (2005). Statistics for experinters: Design, innovation and discovery 2 nd edition.

[12] Greenland, D. (1994). Soil science and sustainable land management. Soil science and sustainable land management in the tropics, 1-15.

[13] Herman, M. C. (2011). Inorganic fertilizer vs. cattle manure as nitrogen sources for maize (Zea Mays L.) in Kakamega, Kenya. The Journal of undergraduate research at Ohio State, 2(1).

[14] Kariuki, J. G. (2011). The future of agriculture in Africa (The Pardee Paper No. 15). Boston: Boston University.

[15] Kelton, W. D. (1999). Designing simulation experiments. Proceedings of the 1999 winter simulation conference, (pp. 33-38). Cincinnati-OH.

[16] Kenya National Bureau of Statistics. (2016). Economic survey. Nairobi: Government of Kenya.
[17] Kibunja, C. N. (2007). Nutrient dynamics and soil microbial deversity (Unpublished $\mathrm{PhD}$ Thesis). Nairobi: University of Nairobi.

[18] Kihanda, F. M., Warren, G. P., \& Michemi, A. N. (2006). Effects of manure application on crop yield and soil chemical properties in a long-term trial of semi-arid Kenya. Nutrient Cycling in Agroecosystems, 76, 341-354.

[19] Kimetu, J. M., Lehamann, J., Ngoze, S. O., Mugendi, D. N., Kinyangi, J. M., Riha, S., et al. (2008). Reversibility of soil productivity decline with organic matter of deffering quality along a degradation gradient. Ecosystems, 11, 726-739.

[20] Maat, H. (2011). The history and future of agricultural experiments. NJAS-WageningenJournal of Life Sciences, 57, 187-195.

[21] Merbach, I., \& Schulz, E. (2013). Long-term fertilization effects on crop yields, soil fertility and sustainability in the static fertilization experiement bad lauch. Archives of agronomy and soil sciences, 1041-1057.

[22] Ministry of Agriculture. (2010). Agricultural sector development strategy. Nairobi: Government of Kenya.

[23] Ministry of Agriculture, Livestock and Fisheries. (2013). Economic review of agriculture. Nairobi: Government of Kenya.

[24] Ministry of Agriculture, Livestock and Fisheries. (2014). Soil suitability evaluation for maize production in Kenya. Nairobi, Kenya: Government of Kenya.

[25] Ministry of Planning. (2008). Vision 2030. Nairobi: Government of Kenya.

[26] Mucheru-Muna, M., Mugendi, D., Pyres, P., Mugwe, J., Kungu, J., Vanlauwe, B., et al. (2013). Enhancing maize productivity and profitability using organic inputs and mineral fertilizer in Central Kenya smallhold farms. Experimental Agriculture, 50, 250-269.

[27] Mugwe, J., Mugendi, D., Mucheru-Muna, M., Odee, D., \& Mairura, F. (2009). Effect of selected organic materials and inorganic fertilizer on the soil fertility of a humnic soil nitisol in the Central Highlands of Kenya. Soiluse and Mananagement, 25, 434-440.

[28] Musinguzi, P., Ebanyat, P., Tenywa, J. S., Basamba, T. A., Tenywa, M. M., \& Mubiru, D. N. (2016). Critical soil organic carbon range for optimal crop response to mineral fertiser Nitrogen on ferralsol. Experimental Agriculture, 1-19.

[29] Richards, P. (1989). Farmers also expement:a neglected intellectual resource in African science. Quality and Reliability Engineering International, 3, 227-240.

[30] Swift, J. M., Izac, A.-M. N., \& Noordwijk van, M. (2004). Biodiversity and ecosystem services in agricultural landscapes-are we asking the right questions? Agriculture, Ecosystems and Environment (104), 113-114.

[31] Wass, J. (2010). First steps in experimental design-the screening experiment. Journal of validation technology, 49-57. 